\title{
Globalization From Below: Toward a Collectively Rational and Democratic Global Commonwealth ${ }^{*}$
}

\section{Christopher Chase-Dunn}

University of California-Riverside

Waves of Decolonization

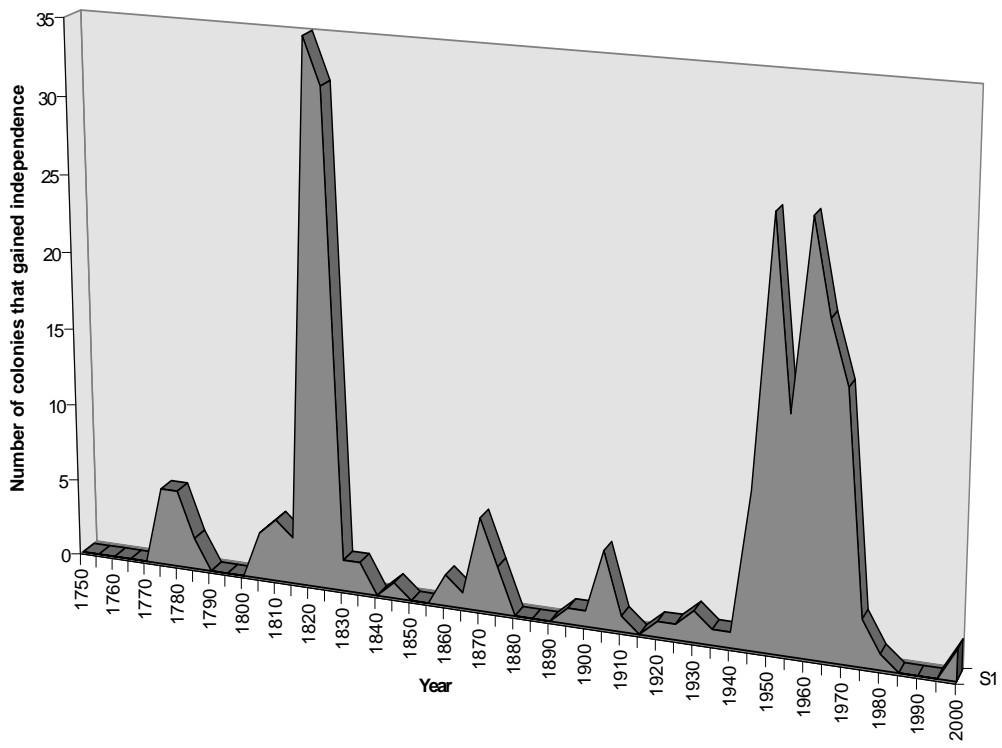

Waves of Decolonization

Main Source: Henige 1970. Colonial empires of Britain, Italy, Japan, the Netherlands, Portugal, Spain, France and the United States were coded.

Social Evolution \& History, Vol. 2 No. 1, March 2003 195-237

(C) 2003 'Uchitel' Publishing House 


\section{ABSTRACT}

This essay presents a world historical perspective on globalization and the relationship between capitalist development and antisystemic movements. It explores the emergence of new popular forces in the world polity, and the possibility of constructing a democratic and collectively rational global commonwealth in the next decades. The idea of 'globalization from below' is considered in the context of Central American countries and possible contributions by post-communist societies are considered.

This essay employs the world-systems perspective on the development of the capitalist world-economy as the framework for analyzing globalization and the possibilities for reorganizing the global system ${ }^{1}$. The world-systems perspective is an historical and structural theoretical framework that analyses national societies as parts of a larger stratified socio-political and economic system.

The focus is on the structural features of the larger system itself. It is a world economy with a hierarchical division of labor for the production of different kinds of goods. There are economically and militarily powerful countries in the core, dependent and dominated regions in the periphery, and a middle sector of countries (the semiperiphery) in which states have intermediate levels of economic and political/military power.

The world market includes both international trade and all the national economies, so the world-system is the whole system, not just international relations. Local, regional, national, international, transnational and global networks of interaction constitute the world-system. This set of nested and overlapping networks of human interaction is itself located in the biosphere and the physical regimes of the planet Earth, the solar system, our galaxy and the larger processes and structures of the physical universe. The worldsystems perspective is both materialist and institutional. It analyses the evolution of human institutions taking account of the constraints and opportunities posed by physics, biology and the natural environment (Chase-Dunn and Hall 1997).

The modern world-system is a global set of interaction networks that include all the national societies. But world-systems have not always been global. The modern world-system originated 
out of an expanding multi-core Afro-Eurasian world-system in which the Europeans rose to hegemony by conquering the Americas and using the spoils to overcome the political and economic strengths of contending core regions in South and East Asia (Frank 1998). The result was a global world-system with a single core region. And, because capitalism had become a predominant mode of accumulation in the European core, European hegemony further extended commodification and markets to the rest of the world. The consequence was a capitalistic and globalizing world economy in which states and firms were increasingly focused on competitiveness in commodity production for the global market. Commodification was always much more developed in core regions, whereas in peripheral regions core colonizers used remnants of the tributary modes of accumulation, especially coercive labor control, to mobilize production for profit. Core regions specialized in the production of capital-intensive goods that required skilled and educated labor, and so their class structures and political institutions became more egalitarian and democratic relative to the authoritarianism and much greater internal inequalities of most peripheral and many semiperipheral countries.

Europe's position within, and relations with, the larger Afroeurasian system heavily affected these developments. But the virulent form of capitalism that emerged in Europe was unique in some important respects. For the first time core states were dominated by capitalists, and the most capitalist states in the European interstate system were the most successful and powerful states. This restructured the pattern of rise and fall (centralization /decentralization) within interstate systems. Earlier systems oscillated between 'universal' states created by semiperipheral marchers and more multicentric state systems. The modern system continued a cycle of centralization/decentralization but this took the form of the rise and fall of capitalist hegemons - the Dutch in the $17^{\text {th }}$ century, the British in the $19^{\text {th }}$ century and the United States in the $20^{\text {th }}$ century. In this new pattern of rise and fall formerly semiperipheral capitalist states acted effectively to prevent the takeover of the core region by tributary marcher states (Spain, France and Germany).

The 'capitalism' referred to here is not only the phenomenon of capitalist firms producing commodities, but also capitalist states 
and the modern interstate system that is the political backdrop for capitalist accumulation. The world-system perspective has produced an understanding of capitalism in which geopolitics and interstate conflict are normal processes of capitalist political competition. Socialist movements are, defined broadly, those political and organizational means by which people try to protect themselves from market forces, exploitation and domination and to build more cooperative institutions. The sequence of industrial revolutions by which capitalism has restructured production and the control of labor have stimulated a series of political organizations and institutions created by workers to protect their livelihoods. This happened differently under different political and economic conditions in different parts of the world-system. Skilled workers created guilds and craft unions. Less skilled workers created industrial unions. Sometimes these coalesced into labor parties that played important roles in supporting the development of political democracies, mass education and welfare states (Ru-eschemeyer, Stephens, and Stephens 1992). In other regions workers were less politically successful, but managed at least to protect access to rural areas or subsistence plots for a fallback or hedge against the insecurities of employment in capitalist enterprises. To some extent the burgeoning contemporary 'informal sector' provides such a fallback.

The varying success of workers' organizations also had an impact on the further development of capitalism. In some areas workers or communities were successful at raising the wage bill or protecting the environment in ways that raised the costs of production for capital. When this happened capitalists either displaced workers by automating them out of jobs or capital migrated to where fewer constraints allowed cheaper production.

The process of capital flight is not a new feature of the worldsystem. It has been an important force behind the uneven development of capitalism and the spreading scale of market integration for centuries. Labor unions and socialist parties were able to obtain some power in certain states, but capitalism became yet more international. Firm size increased. International markets became more and more important to successful capitalist competition. Fordism, the employment of large numbers of easily organizable workers in centralized production locations, has been supplanted by 'flexible accumulation' (small firms producing small custom- 
ized products) and global sourcing (the use of substitutable components from widely-space competing producers), production strategies that makes traditional labor organizing approaches much less viable.

Focusing on the systemic dynamics of this 'modern' Europecentered world-system produces a model of systemic constants, cycles and trends within which the musical chairs game of geopolitics and economic competition have occurred (Chase-Dunn 1998: $\mathrm{XIV}-\mathrm{XVI}$ ). This model is the structural and dynamic backdrop for this analysis of systemic transformation, the spiral of capitalism and socialism and the roles that transnational social movements are likely to play in the future.

The combination of these structural constants, cycles and trends produces a model of world-system structure that reproduces its basic features while growing and intensifying. I contend contra widely accepted contentions to the contrary that the world-system has not fundamentally changed in recent decades as regards its basic structural features. Most of the events that are depicted as new departures are in fact continuations of cycles and trends long in operation. In Global Formation (Chase-Dunn 1989: Chapters 3 and 4) I argued that the 'stages of capitalism' literature could be analytically specified by the model of world-system constants, cycles and trends without the loss of any structural or processual features of importance. The more recent discourse on flexible specialization and globalization has failed to alter my view that the modern world-system is continuing on a developmental trajectory that is centuries old. But, Giovanni Arrighi's (1994) study of 'systemic cycles of accumulation' (SCAs) adds an important evolutionary dimension to the basic world-system model by teasing out the important organizational differences that distinguished the Genoese, Dutch, British and United States SCAs. The only thing lacking from Arrighi's analysis is an evolutionary focus on the role played by oppositional forces. With this addition the world-system model will be ready for the next task - how to transform the contemporary system into something more desirable from the point of view of the vast majority of the human species.

Theories of social structure provoke a standard set of criticisms. They are allegedly deterministic and downplay the importance of human agency. They are accused of reifying the idea of society (or 
the world-system) whereas only individual persons are alleged to really exist and to have needs. Structural theories, it is charged, totalize experience and provide ideological covers for domination and exploitation. And they miss the rich detail of locality and period that only thick description can provide.

The world-systems perspective has been accused of all these sins. In this essay I will describe a model of the structures and processes of the modern world-system and propose a project to transform the contemporary system into a democratic and collectively rational global commonwealth. This involves an approach to structure and action first outlined by Frederick Engels in his Socialism: Utopian and Scientific (1935). The point of building a structural theory is to enable us to understand the broad dynamics of social change in the historical system in which we live. This knowledge is potentially useful to those who want to preserve, modify or transform the historical system. For Engels the point was to mobilize the working class to humanize and socialize the world. That is also my intention.

The approach developed here assumes a structural model of the world-system and it identifies the agents who have both the motive and the opportunity to transform the contemporary world-system into a global socialist commonwealth. I also discuss some of the value-bases and the organizational issues that surround the project of transformation. By presenting the model in this way I hope to show the critics of structuralism that structural theories need not be deterministic, nor need they undermine social action. By positively stating the model and its implications for action I hope to get those who would be critical of the modern system to focus on the problems of scientifically understanding and transforming that system.

The scientific approach to world-system transformation needs to avoid the teleological elements of much of Marxism. The ideology of progress has been used to glorify both capitalism and socialism. Progress is not an inevitable outcome of forces that are immanent the world. The idea of progress only means that many humans can agree about the basics of what constitutes a good life. These are value judgments. But by making these assumptions explicit we can determine whether or not social change really constitutes progress as defined. 
Inevitabilism also needs to be renounced. Human social change is both historical and evolutionary, but there is nothing inevitable about it. Indeed, another big asteroid or a human-made ecological catastrophe could destroy the whole experiment. Teleology is the idea that progress is inevitable because it comes out of the nature of the universe, or the nature of history, or some other powerful source. For many Marxists the proletariat has been understood to be the agency of progress. It is important to disentangle the scientific from the unscientific aspects of this idea. Workers may have interests that are compatible with and encourage the development of a more humane system, but that is not the same as being a magical source of historical progress. Teleology, inevitabilism, and eschatology are powerful bromides for the mobilization of social movements, but they are deceptive and counter-productive when the prophesied utopia fails to arrive. What is needed is an openended theory of history that can be useful for practitioners of the arts of transformation. The world-systems perspective can serve this purpose.

\section{TYPES OF GLOBALIZATION}

The discourse about globalization has used this term to mean several different things. For some globalization means a new stage of global capitalism that is qualitatively different from a prior stage that recently ended, though the ways in which it is alleged to be different vary from author to author. I will distinguish between two main meanings of the term 'globalization':

- international integration, and

- the political-ideological discourse of global competitiveness.

Globalization as international integration needs to be further unpacked as international economic integration, international political integration and international cultural and communications integration. Of course each of these subtypes has many aspects. But the point here is that the question of international integration is an objective problem of the extensiveness and intensity of links in a set of global networks of interaction. We can determine empirically how economically integrated were the societies on Earth in the late nineteenth century and how 'economically globalized' the 
world economic network is now (Chase-Dunn, Kawano, and Brewer 2000). This is a question that is separable from the consciousness that people have about their linkages with one another. The question of consciousness regarding linkages (social cosmology) also needs to be studied, and this second main type of globalization will also be considered below.

\section{GLOBALIZATION AS IDEOLOGY}

Since the 1980s the term 'globalization' has been used to describe allegedly recent and important changes in the world economy. It generally refers to changes in technologies of communication and transportation, increasingly internationalized financial flows and commodity trade, and the transition from national to world markets as the main arena for economic competition. These ostensible changes have been used to justify economic and political decisions such as deregulation and privatization of industries, downsizing and streamlining of work forces, and dismemberment of the welfare services provided by governments. The expansion of the global economy has also been painted as the victory of progressive and rational capitalism over the anachronistic ideologies of socialism and communism. People naturally want more and bigger and faster commodities, and global capitalism is alleged to be the most efficient feasible system for providing these.

This discourse about globalization is itself a phenomenon worthy of social science research. The emergence of neo-liberal political ideology is the topic of Phillip McMichael's (1996) analysis of the 'globalization project'. This phenomenon emerged with Reaganism and Thatcherism in the 1980s and has swept around the world as a justification for attacking and dismantling welfare states and labor unions following the demise of the Soviet Union. How did this somewhat revised and expanded rendition of the private property version of the European Enlightenment become the global hegemonic ideology at the end of the twentieth century?

While political commentators have dubbed this collection of aphorisms about the magic of the market 'the Washington Consensus', the term I prefer for this turn in global discourse is 'neoliberalism'. The beginning of worldwide decline of the political left may have predated the revolutions of 1989 and the demise of the 
Soviet Union, but it was certainly also accelerated by these events. The structural basis of the rise of the globalization project is the new level of integration reached by the global capitalist class. The internationalization of capital has been an important part of the trend toward economic globalization for centuries. And there have been many claims to represent the general interests of business before. Indeed every modern hegemon has made this claim. But the real integration of interests of the capitalists in each of the core states has reached a level greater than ever before in the most recent wave of economic globalization.

This is the part of the model of a global stage of capitalism that must be taken most seriously, though it can certainly be overdone. The world-system has now reached a point at which both the old interstate system based on separate national capitalist classes, and new institutions representing the global interests of capitalists exist and are powerful simultaneously. In this light each country can be seen to have an important ruling class fraction that is allied with the transnational capitalist class.

Neo-liberalism began as the Reagan-Thatcher attack on the welfare state and labor unions. It evolved into the Structural Adjustment Policies of the International Monetary Fund and the triumphalism of the ideologues of global corporations after the demise of the Soviet Union. In United States foreign policy it has found expression in a new emphasis on 'democracy promotion' in the periphery and semiperiphery. Rather than propping up military dictatorships in Latin America, the emphasis has shifted toward coordinated action between the C.I.A and the U.S. National Endowment for Democracy to promote electoral institutions in Latin America and other semiperipheral and peripheral regions (Robinson 1996). Robinson contends that the kind of 'low intensity democracy' that is promoted is best comprehended as 'polyarchy' - a regime form in which elites orchestrate a process of electoral competition and governance that legitimates state power and undercuts more radical political alternatives that might threaten the ability of national elites to maintain their wealth and power by exploiting workers and peasants. Robinson (1996) convincingly argues that polyarchy and democracy-promotion are the political forms that are most congruent with a globalized and neo-liberal world econ- 
omy in which capital is given free reign to generate accumulation wherever profits are greatest.

\section{STRUCTURAL GLOBALIZATION}

Human societies are composed of interaction networks and the institutions and forms of consciousness that make various kinds of interaction possible. The world-systems perspective asserts that interaction networks have been importantly intersocietal since at least the emergence of cities and states, but comparative studies reveal important intersocietal interaction networks even in systems composed entirely of nomadic hunters (Chase-Dunn and Hall 1997).

While the institutional nature of interaction networks has undergone major transformations with the evolution of social complexity and hierarchy, one important aspect of interaction networks has always been their spatial scale and the relative intensity of smaller and larger nets. Comparative research reveals that all world-systems small and large have exhibited the phenomenon of 'pulsation' in which exchange networks alternately expand and contract. For the modern world-system I will conceptualize globalization as, in part, changes in the intensity of international and global interactions relative to the local or national networks. If both national level and global networks increase in intensity at the same rate, this approach does not see an increase in the globalization of interaction. Globalization in this structural sense is both integration and interdependence ${ }^{2}$.

Different kinds of interaction have long had different spatial attributes. Most world-systems are multicultural in the sense that important political/military and trade interactions link groups with very different languages and cultures. The modern world-system is mainly composed of national cultures, though the most powerful countries have long been able to impose, sell or diffuse their cultural characteristics widely, and there may now be emerging a truly global culture that is more than just the cultural reach of the most powerful national states (Meyer 1996; Boli and Thomas 1997).

Structural economic and political globalization are conceptualized here as the differential density and power of larger vs. small interaction networks and organizations. Though we do not contend 
that politics and economics are separate realms that can be independent objects of scientific inquiry, we do find it convenient to distinguish between political and economic forms of globalization.

Economic globalization means greater integration in the organization of production, distribution and consumption of commodities in the world-economy. We are all aware that our breakfasts have been increasingly coming from distant locations. Sugar has importantly been a global commodity for centuries, in the sense that intercontinental market forces and the policies of competing states have massively affected both its conditions of production and consumption. But fresh grapes have only become global commodities since jets started transporting them between the southern and northern hemispheres. If you do not eat sugar or grapes for breakfast, no matter. The energy that was used to produce whatever you eat has long been a global commodity as well, though there have been important changes in the nature of energy production, the organizational structures and ownership of energy-producing firms and the impact of state policies on energy production and consumption (Podobnik 1999).

Political globalization is here conceptualized as the institutional form of global and inter-regional political/military organizations (including 'economic' ones such as the World Bank and the International Monetary Fund), and their strengths relative to the strengths of national states and other smaller political actors in the world-system. This is analogous to the conceptualization of economic globalization as the relative density and importance of larger versus smaller interaction networks.

\section{ECONOMIC GLOBALIZATION IS BOTH A LONG-TERM TREND AND A CYCLICAL PHENOMENON}

If we calculate the ratio of international investments to investments within countries, the world economy had nearly as high a level of 'investment globalization' in 1910 as it did in 1990 (Bairoch 1996). Similarly, if we estimate the degree of trade globalization, there has been both a long-term trend and three waves of globalization - one in the last half of the nineteenth century, a small one from 1900 to 1929, and a large upswing from 1950 to the present 
(Chase-Dunn, Kawano, and Brewer 2000) (see Figure 1).

Average Openness TradeGdbalization (5year movingaverage)

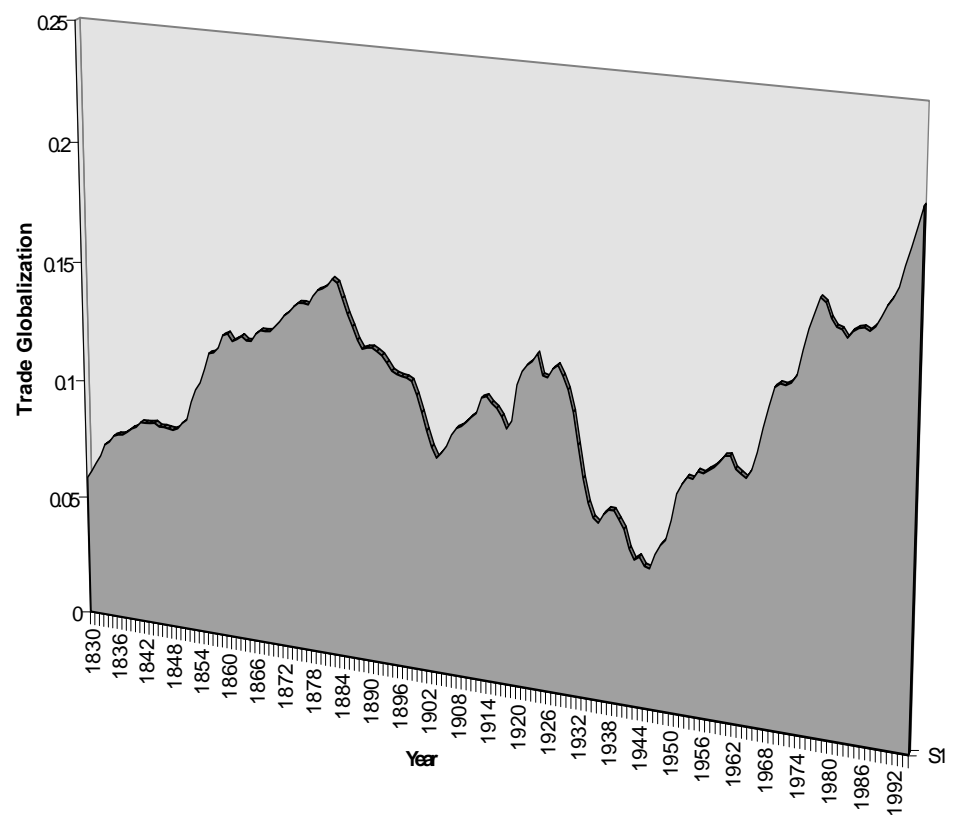

Figure 1: Average Openness: Trade Globalization, 1830-1995 (Weighted)

(Source: Chase-Dunn, Kawano, and Brewer 2000)

The point here is that globalization as international economic integration needs to be understood as part of a long-term set of processes that have characterized the world-system for centuries. This model of the structural constants, cycles and secular trends specifies the basic and normal operations of the system, and I argue elsewhere that this basic schema continues to describe the system in the current period of global capitalism (Chase-Dunn 1998).

\section{THE SPIRAL OF CAPITALISM AND SOCIALISM}

In core countries certain sectors of the working classes were able to 
mobilize political power and raise wages through trade unions and socialist parties. This was made possible by core capital's need for skilled and educated labor. The relatively more democratic political institutions and the development of welfare programs were mainly based on the political efforts of skilled and organized workers (Rueschemeyer, Stephens, and Stephens 1992). In some core countries the relative harmony of class relations was also supplemented by the extraction of profits from peripheral regions and the availability of cheap food and raw materials provided by core domination and exploitation of the periphery.

At some times and places the movements of core workers took a more radical turn and threatened the political hegemony of capital, but the long run outcome in the core states was not socialist revolution, but rather the construction of social democratic welfare states or the sort of business unionism that emerged in the United States.

In the periphery colonial elites used coerced labor (serfdom, slavery, indentured servitude) to produce commodities for export to the core. But resistance in the periphery from peasants and workers, as well as nationalist movements supported by small middle class groups, led to effective anti-imperialist coalitions that were able to achieve decolonization and the rudiments of national sovereignty. These movements created anti-imperial class alliances that, after World War II, often utilized socialist ideology. But most of the resultant regimes remained quite dependent on neo-colonial relations with capitalist core states. Radical challenges to capitalism in the most of the periphery were easily disrupted by overt or covert intervention. Vietnam was a significant exception.

In the world-system framework the Communist states represented efforts by popular movements in the semiperiphery and the periphery to transform the capitalist world-system into a socialist world-system, but also to catch up with core capitalism in terms of economic development. These efforts largely failed because they were not able to transcend the institutional constraints of the capitalist world-economy and because the capitalist core states were spurred to develop new technologies of production, politi$\mathrm{cal} /$ military control and global market and political integration in response to the challenges posed by the Communist states. The long run relationship between capitalism and anti-capitalist move- 
ments as a spiral in which the contestants provoke each other to ever greater feats of mobilization and integration (Boswell and Chase-Dunn 2000).

In some countries in the semiperiphery radical challenges to capitalism were able to take state power and to partially institutionalize socialist economic institutions. There were great limitations on what was possible despite the fact that there were true revolutions of workers and peasants in Russia, China, Cuba, Yugoslavia, Korea, Albania and Vietnam.

Socialism in one country was not what the Bolsheviks had in mind. They thought that there would be a world revolution against capitalism after World War I, or at least a revolution in Germany. The decision to hang on in Russia despite the failure of radical regimes to come to power elsewhere may have been a grave mistake. It required the use of both socialist ideology and substantial coercion simply to maintain Communist state power and to mobilize industrialization, urbanization and education to catch up with core capitalism. This contradiction was already apparent in the time of Lenin. Stalin did not look back.

It was the military part of this equation that was probably the most costly economically and politically. Military-style mass production became the model for the whole 'socialist' economy in Russia (Boswell and Peters 1990). Building and supporting a Soviet Army that was capable of halting the advance of Germany in World War II meant further concentration of power in the Communist Party, the complete elimination of democracy within the party, and the use of the Communist International as purely the instrument of Russian international interests. The humiliation of the Hitler-Stalin pact and its reversal branded Communism as a form of totalitarianism equivalent to fascism in the minds of millions of democratic socialists all over the globe, as well as playing into the hands of the ideologues of capitalism.

Chirot (1991) and Lupher (1996) argue that Stalinism was mainly a continuation of Russian bureaucratic patrimonialism or oriental despotism. I reject this sort of institutional determinism. I see both structural constraints and historical possibilities. The authoritarian outcome of the Russian revolution was not predetermined, but it was greatly conditioned by Russia's semiperipheral 
location and the military and economic forces that were brought to bear from the capitalist core states. I agree with Hobsbawm (1994) that this does not excuse the Stalinist repression, but our analysis leaves open the possibility of past and future systemic transformation, while the continuationist frame sees only the end of history.

The Chinese, Cuban, Korean, Yugoslavian, Albanian and Vietnamese revolutions benefited somewhat from the political space opened up by the Soviet Union. The idea that there was a real alternative to the end of history in the capitalist version of the European Enlightenment was kept alive by the existence of the Soviet Union, despite its grave imperfections. The Chinese, Cuban, Korean, Yugoslavian, Albanian and Vietnamese revolutions were able to learn from Russian mistakes to some extent, and to try new directions and make mistakes of their own. The most obvious example was Mao's turn to the peasantry. While the Bolsheviks had treated peasants as a conservative foe (despite Lenin's analysis), thus putting the Party at odds with the majority of the Russian people, Mao embraced the peasantry as a revolutionary class. The later revolutions also benefited from the maneuverability that Soviet political/military power in the world-system made possible.

The regimes created in Central and Eastern Europe by the Red Army after World War II are a different breed of cat. In these, socialist ideology and Stalinist development policies were imposed from outside, so they were never politically legitimate in the eyes of most of the population. This major structural fact varied to some extent depending on the strength of pre-existing socialist and communist forces before the arrival of the Red Army. The Soviet Union justified its intervention in terms of "proletarian internationalism' and creating a buffer zone against the Germans. While the geopolitical justification was plausible from the Russian point of view, it did not help to justify the regimes of the Eastern European countries with their own populations. And the noble ideal of proletarian internationalism was besmirched by its use as a fig leaf for setting up these puppet regimes.

Jozsef Borozc's (1999: Table 1) analysis of these Eastern and Central European 'comprador' regimes details the many compromises that the Soviet overlords introduced in order to increase internal legitimacy. But because of the origin of these regimes in 
world geopolitics, the legitimacy problem was insoluble. Revolts were crushed by Russian tanks, but the basic problem of legitimacy eventually led to the overthrow of every one of these regimes as soon as the Soviet fist was lifted by Gorbachev.

\section{POLITICAL IMPLICATIONS OF THE WORLD-SYSTEM PERSPECTIVE}

Thus class struggles and anti-imperial movements have been important shapers of the institutional structures of modern capitalism for centuries. The waves of globalization of capitalism in the twentieth century were stimulated in important ways by the challenges posed by the Leninist parties and the Communist states. Contrary to the view that history has ended, anti-capitalist movements will continue to emerge in response to expanding and intensifying capitalist development. The most recent wave of transnational economic integration and the political ideology of neo-liberal restructuring, down-sizing and 'competitiveness' is provoking workers, peasants, women, indigenous groups and defenders of the biosphere to mobilize. Some of the resulting movements may employ localist and nationalist organizational structures to protect against market forces and transnational capital, but retreat into xenophobic nationalism might be a recipe for another round of world war. The only effective response will be to organize 'globalization from below' - transnational social movements with the goal of building an Earth-wide collectively rational and democratic commonwealth.

The age of U.S. hegemonic decline and the rise of postmodernist philosophy have cast the liberal ideology of the European Enlightenment (science, progress, rationality, liberty, democracy and equality) into the dustbin of totalizing universalisms. It is alleged that these values have been the basis of imperialism, domination and exploitation and, thus, they should be cast out in favor of each group asserting its own set of values. Note that selfdetermination and a considerable dose of multiculturalism (especially regarding religion) were already central elements in Enlightenment liberalism.

The structuralist and historical materialist world-systems approach poses this problem of values in a different way. The problem with the capitalist world-system has not been with its values. 
The philosophy of liberalism is fine. It has quite often been an embarrassment to the pragmatics of imperial power and has frequently provided justifications for resistance to domination and exploitation. The philosophy of the enlightenment has never been a major cause of exploitation and domination. Rather, it was the military and economic power generated by capitalism that made European hegemony possible.

To humanize the world-system we may need to construct a new philosophy of democratic and egalitarian liberation. Of course, many of the principle ideals that have been the core of the Left's critique of capitalism are shared by non-European philosophies. Democracy in the sense of popular control over collective decision-making was not invented in Greece. It was a characteristic of all non-hierarchical human societies on every continent before the emergence of complex chiefdoms and states (Bollen, and Paxton 1997). My point is that a new egalitarian universalism can usefully incorporate quite a lot from the old universalisms. It is not liberal ideology that caused so much exploitation and domination. Rather, it was the failure of real capitalism to live up to its own ideals (liberty and equality) in most of the world. That is the problem that progressives must solve.

A central question for any strategy of transformation is the question of agency. Who are the actors who will most vigorously and effectively resist capitalism and construct democratic socialism? Where is the most favorable terrain, the weak link, where concerted action could bear the most fruit? Samir Amin (1990, 1992) contends that the agents of socialism have been most heavily concentrated in the periphery. It is there that the capitalist worldsystem is most oppressive, and thus peripheral workers and peasants, the vast majority of the world proletariat, have the most to win and the least to lose.

On the other hand, Marx and many contemporary Marxists have argued that socialism will be most effectively built by the action of core proletarians. Since core areas have already attained a high level of technological development, the establishment of socialized production and distribution should be easiest in the core. And, organized core workers have had the longest experience with industrial capitalism and the most opportunity to create socialist social relations. I submit that both 'workerist' and 'Third Worldist' posi- 
tions have important elements of truth, but there is another alternative, that is suggested by the structural theory of the world-system: the semiperiphery as the weak link.

Core workers may have experience and opportunity, but a sizable segment of the core working classes lack motivation because they have benefited from a nonconfrontational relationship with core capital. The existence of a labor aristocracy has divided the working class in the core and, in combination with a large middle stratum, has undermined political challenges to capitalism. Also, the 'long experience' in which business unionism and social democracy have been the outcome of a series of struggles between radical workers and the labor aristocracy has created a residue of trade union practices, party structures, legal and governmental institutions, and ideological heritages which act as barriers to new socialist challenges. These conditions have changed to some extent during the last two decades as hyper-mobile capital has attacked organized labor, dismantled welfare states and downsized middle class work forces. These create new possibilities for popular movements within the core, and we can expect more confrontational popular movements to emerge as workers devise new forms of organization (or revitalize old forms). Economic globalization makes labor internationalism a necessity, and so we can expect to see the old idea take new forms and become more organizationally real. Even small victories in the core have important effects on peripheral and semiperipheral areas because of demonstration effects and the power of core states.

The main problem with 'Third Worldism' is not motivation, but opportunity. Democratic socialist movements that take state power in the periphery are soon beset by powerful external forces that either overthrow them or force them to abandon most of their socialist program. Popular movements in the periphery are most usually anti-imperialist class alliances which succeed in establishing at least the trappings of national sovereignty, but not socialism. The low level of the development of the productive forces also makes it harder to establish socialist forms of accumulation, although this is not impossible in principle. It is simply harder to share power and wealth when there are very little of either. But, the emergence of democratic regimes in the periphery will facilitate new forms of mutual aid, cooperative development and popular movements once 
the current ideological hegemony of neoliberalism has broken down.

\section{SEMIPERIPHERAL DEMOCRATIC SOCIALISM}

In the semiperiphery both motivation and opportunity exist. Semiperipheral areas, especially those in which the territorial state is large, have sufficient resources to be able to stave off core attempts at overthrow and to provide some protection to socialist institutions if the political conditions for their emergence should arise. Semiperipheral regions (e.g., Russia and China) have experienced more militant class based socialist revolutions and movements because of their intermediate position in the core/periphery hierarchy. While core exploitation of the periphery creates and sustains alliances among classes in both the core and the periphery, in the semiperiphery an intermediate world-system position undermines class alliances and provides a fruitful terrain for strong challenges to capitalism. Semiperipheral revolutions and movements are not always socialist in character, as we have seen in Iran. But, when socialist intentions are strong there are greater possibilities for real transformation than in the core or the periphery. Thus, the semiperiphery is the weak link in the capitalist world-system. It is the terrain upon which the strongest efforts to establish socialism have been made, and this is likely to be true of the future as well.

On the other hand, the results of the efforts so far, while they have undoubtedly been important experiments with the logic of socialism, have left much to be desired. The tendency for authoritarian regimes to emerge in the communist states betrayed Marx's idea of a freely constituted association of direct producers. And, the imperial control of Eastern Europe by the Russians was an insult to the idea of proletarian internationalism. Democracy within and between nations must be a constituent element of true socialism.

It does not follow that efforts to build socialism in the semiperiphery will always be so constrained and thwarted. The revolutions in the Soviet Union and the Peoples' Republic of China have increased our collective knowledge about how to build socialism despite their only partial successes and their obvious failures. It is important for all of us who want to build a more humane and 
peaceful world-system to understand the lessons of socialist movements in the semiperiphery, and the potential for future, more successful, forms of socialism there.

Once again the core has developed new lead industries - computers and biotechnology - and much of large-scale heavy industry, the classical terrain of strong labor movements and socialist parties, has been moved to the semiperiphery. This means that new socialist bids for state power in the semiperiphery (e.g., South Africa, Brazil, Mexico, perhaps Korea) will be much more based on an urbanized and organized proletariat in large scale industry than the earlier semiperipheral socialist revolutions were. This should have happy consequences for the nature of new socialist states in the semiperiphery because the relationship between the city and the countryside within these countries should be less antagonistic. Less internal conflict will make more democratic socialist regimes possible, and will lessen the likelihood of core interference. The global expansion of communications has increased the salience of events in the semiperiphery for audiences in the core and this may serve to dampen core state intervention into the affairs of democratic socialist semiperipheral states.

Some critics of the world-systems perspective have argued that emphasis on the structural importance of global relations leads to political do-nothingism while we wait for socialism to emerge at the world level. The world-system perspective does indeed encourage us to examine global level constraints (and opportunities), and to allocate our political energies in ways that will be most productive when these structural constraints are taken into account. It does not follow that building socialism at the local or national level is futile, but we must expend resources on transorganizational, transnational and international socialist relations. The environmental and feminist movements are now in the lead and labor needs to follow their example.

A simple domino theory of transformation to democratic socialism is misleading and inadequate. Suppose that all firms or all nation states adopted socialist relations internally but continued to relate to one another through competitive commodity production and political/military conflict. Such a hypothetical world-system would still be dominated by the logic of capitalism, and that logic would be likely to repenetrate the 'socialist' firms and states. This 
cautionary tale advises us to invest political resources in the construction of multilevel (transorganizational, transnational and international) socialist relations lest we simply repeat the process of driving capitalism to once again perform an end run by operating on a yet larger scale.

\section{A DEMOCRATIC SOCIALIST WORLD-SYSTEM}

These considerations lead us to a discussion of socialist relations at the level of the whole world-system. The emergence of democratic collective rationality (socialism) at the world-system level is likely to be a slow process. What might such a world-system look like and how might it emerge? It is obvious that such a system would require a democratically controlled world federation that can effectively adjudicate disputes among nation states and eliminate warfare (Goldstein 1988). This is a bare minimum. There are many other problems that badly need to be coordinated at the global level: ecologically sustainable development, a more balanced and egalitarian approach to economic growth, and the lowering of population growth rates.

The idea of global democracy is important for this struggle. The movement needs to push toward a kind of popular democracy that goes beyond the election of representatives to include popular participation in decision-making at every level. Global democracy can only be real if it is composed of civil societies and national states that are themselves truly democratic (Robinson 1996). And global democracy is probably the best way to lower the probability of another war among core states. For that reason it is in everyone's interest.

How might such a global social democracy come into existence? The process of the growth of international organizations that has been going on for at least 200 years will eventually result in a world state if we are not blown up first. Even international capitalists have some uses for global regulation, as is attested by the International Monetary Fund and the World Bank. Capitalists do not want the massive economic and political upheavals that would likely accompany collapse of the world monetary system, and so they support efforts to regulate 'ruinous' competition and beggar-thy-neighborism. Some of these same capitalists also fear nu- 
clear holocaust, and so they may support a strengthened global government that can effectively adjudicate conflicts among nation states.

Of course, capitalists know as well as others that effective adjudication means the establishment of a global monopoly of legitimate violence. The process of state formation has a long history, and the king's army needs to be bigger than any combination of private armies that might be brought against him. While the idea of a world state may be a frightening specter to some, I am optimistic about it for several reasons. First, a world state is probably the most direct and stable way to prevent nuclear holocaust, a desideratum that must be at the top of everyone's list. Secondly, the creation of a global state that can peacefully adjudicate disputes among nations will transform the existing interstate system. The interstate system is the political structure that stands behind the maneuverability of capital and its ability to escape organized workers and other social constraints on profitable accumulation. While a world state may at first be dominated by capitalists, the very existence of such a state will provide a single focus for struggles to socially regulate investment decisions and to create a more balanced, egalitarian and ecologically sound form of production and distribution.

The progressive response to neoliberalism needs to be organized at national, international and global levels if it is to succeed. Democratic socialists should be wary of strategies that focus only on economic nationalism and national autarchy as a response to economic globalization. Socialism in one country has never worked in the past and it certainly will not work in a world that is more interlinked than ever before. The old forms of progressive internationalism were somewhat premature, but internationalism has finally become not only desirable but also necessary. This does not mean that local, regional and national-level struggles are irrelevant. They are just as relevant as they always have been. But, they need to also have a global strategy and global-level cooperation lest they be isolated and defeated. Communications technology can certainly be an important tool for the kinds of long-distance interactions that will be required for truly international cooperation and coordination among popular movements. It would be a mistake to 
pit global strategies against national or local ones. All fronts should be the focus of a coordinated effort.

W. Warren Wagar (1996) has proposed the formation of a 'World Party' as an instrument of 'mundialization' - the creation of a global socialist commonwealth. His proposal has been critiqued from many angles - as a throwback to the Third International, etc. I suggest that Wagar's idea is a good one, and that a party of the sort he is advocating will indeed emerge and that it will contribute a great deal toward bringing about a more humane world-system. Self-doubt and post-modern reticence may make such a direct approach appear Napoleonic. It is certainly necessary to learn from past mistakes, but this should not prevent us debating the pros and cons of positive action.

The international segment of the world capitalist class is indeed moving slowly toward global state formation. The World Trade Organization is only the latest element in this process. Rather than simply oppose this move with a return to nationalism, progressives should make every effort to organize social and political globalization, and to democratize the emerging global state. We need to prevent the normal operation of the interstate system and future hegemonic rivalry from causing another war among core powers (e.g., Wagar 1992; see also Chase-Dunn and Bornschier 1998). And, we need to shape the emerging world society into a global democratic commonwealth based on collective rationality, liberty and equality. This possibility is present in existing and evolving structures. The agents are all those who are tired of wars and hatred and who desire a humane, sustainable and fair world-system. This is certainly a majority of the people of the Earth.

\section{GLOBALIZATION FROM BELOW OR DELINKING?: THE GUATEMALAN CASE}

The strategy of globalization from below means linking up women's movements, labor struggles, indigenous movements and agrarian reform movements within regions and globally. Labor movements in Guatemala have already been partially successful in forging new implementations of the old notion of labor internationalism, and in mobilizing support from the United States and other core countries based on concerns about human rights and the 
labor provisions of international trade agreements (Frundt 1987; Armbruster 1998).

The problems of cross-border labor organizing and international labor solidarity are great, but the new organizational terrain of global capitalism requires new strategies (Stevis 1998). Because the globalization project has abrogated social compacts between business and labor within core countries, especially in the United States, there are new possibilities for cooperation between Latin American and U.S. workers and their organizations. John Sweeney, the president of the United States American Federation of Labor - Council of Industrial Organizations (AFL-CIO) visited the leaders of independent unions in Mexico City. This willingness to look at new alliances is a welcome relief from the long-standing Cold War approach to labor internationalism that was AFL-CIO practice until recently. Armbruster (1998) reports that help from the AFL-CIO was an important factor in the organizing success of the workers at the Phillips-Van Heusen plant in Guatemala ${ }^{3}$.

Women's movements in El Salvador have made important efforts to link their struggles with sympathetic groups in other Central American countries and in the United States. Indeed, these groups have explicitly advocated globalization from below. In Mexico the resurgent electoral left, the agrarian movements in Chiapas and Guerrero, and independent trade unions have found that common opposition to neo-liberalism is a uniting force. Some of the popular leaders in Mexico have made an effort to mobilize support from the United States, but not many yet see this as part of a larger effort to democratize both Mexico and the global system.

The emerging popular responses to globalization and neoliberalism face an important and potentially divisive issue. One possibility for mobilizing against global capitalism is 'delinking' and self-reliance. Another, and very different, approach is to respond to global capitalism by building global democracy. The world-systems perspective has much to offer regarding the consideration of the value of these options.

The neo-liberals have pronounced withdrawal from the capitalist world economy as unthinkable and many popular leaders seem to agree. The wonders of technology and communications are alleged to be the highest values, and only by playing the game of 
competitiveness can a developing country have access to these. But some critics are now questioning whether the 'necessity' of openness to the global economy is worth the costs. This is a healthy response because it unmasks many of the ideological presuppositions of neo-liberalism. People need housing, clean water, and healthy food. It is not necessary to be able to program your hair dryer from your car radio. The hyperbole of wonders needs be popped, like the financial bubbles that abound in the virtual space of global money.

The notion that self-reliance is an anachronism needs to be examined in historical perspective. In long-run panorama, protectionism and national mobilization of development have been useful and successful strategies in the past. The semiperipheral national societies that later became hegemons in the Europe-centered world-system all utilized tariff protectionism and state-sponsored mobilization to move themselves up the value-added hierarchy. The communist states used self-reliance and socialist ideology to try to establish a new mode of accumulation, though they ended in trying hardest to catch up with core capitalism. According to neoliberal liturgy free trade and the free movement of capital generates the most optimum development for all. But the successful practice of upward mobility in the world-system demonstrates the value that state intervention and protection of certain activities can have (Evans 1995). The trajectories of the communist states are also alleged to prove the worthlessness of state planning and self-reliant economic nationalism.

I would argue that these strategies did indeed work, though the utopias they were intended to forge did not actually result. Instead capitalism expanded and reincorporated the self-reliant. This picture of challenge and response needs to consider the higher degree of economic and political integration of the current world-system. It is undoubtedly more costly to drop out of more integrated system than to drop out of a less integrated one. So the costs of going it alone have increased. These costs have always been higher for small countries such as those in Central America. This is why small countries have a greater interest in cross-border cooperation among popular movements. But the institutions of nationalism and the existing rules of the interstate system make such cooperation 
difficult.

Popular movements in Guatemala face the issue of whether or not to focus on local and national-level institutions and alliances, or on international and global ones. Would it be more productive to focus on gaining increasing say in the national state and using national sovereignty as a means of providing protection from global market and geopolitical forces, or on the other hand, to make efforts to reform or revolutionize the world-system by making alliances and constructing institutions that promote popular democracy on an international regional or global scale? The national route has a long history and is supported by the existing institutions, while the international route is little understood and is in great need of imagination. Global democracy seems to be only a pair of words to most people in the world today. It can be defined abstractly, but what would it mean in practice?

As within countries, democracy is a contested concept. Robinson's (1996) critique of polyarchy within countries badly needs to be extended to a critique of global-level political institutions such as the International Monetary Fund and the World Bank. International regional and global political institutions should be governed democratically by the peoples whose lives they affect. This would mean popular participation in the election of representatives and in the decision-making of these institutions. Indeed, though the United Nations verification mission (MINUGUA) has played a valuable role in the Guatemalan peace process, the U.N. is itself in need of democratization.

Globalization from below means spending organizational and movement resources on alliances and institution building at the international regional and global levels. In practice neither a purely national strategy nor a purely global one would work for Guatemala or any other country in the contemporary context. So the real problem is to decide upon the mix and to pursue coordinated and complimentary approaches.

\section{POLYARCHY AND BEYOND IN GUATEMALA}

Another issue in the Guatemalan situation is raised by Robinson's analysis. Guatemala has not yet really achieved polyarchy, let alone real democracy. Polyarchy, while it may be largely a smoke 
screen for continued domination and inequality, is undoubtedly better than a country run by the military and over-run with death squads. The implementation of the Peace Accords has gone very slowly. Some observers have wondered if the current government is seriously committed to implementation. But the main problem is that the neo-liberal elite fraction is weak, so it cannot afford to push too hard on the military or the agro-exporting elite families who have mounted a tremendous resistance to the peace process. And indeed the neo-liberals share many interests in common with the older landed elite. Neither is anxious to pay taxes.

Globalization from below in concert with popular forces in other Central American countries and in Mexico would naturally be organized around opposition to neo-liberal policies and institutions. Regional-level demands such as a minimum wage for maquiladora workers could be an important component of this strategy. Opposition to neo-liberal policies could also serve as a unifying strategy for different kinds of popular movements within Guatemala.

It might be supposed that in the Guatemalan situation it would make tactical sense for the popular forces to ally with the transnational neo-liberals and the International Financial Institutions (IFIs) in the short run in order to attain concessions from the agro-export dynasties regarding the fiscal strength of the state and demilitarization. The implementation of the Peace Accords has at least the possibility of establishing the trappings of an electoral democracy with substantial participation from popular sectors. Demilitarization and the establishment of the rule of law may not be true democracy, but they are certainly better for the popular classes than the situation of terror that has long existed and that still exists in some regions of the country. Under these conditions one might conclude that the campaign against neo-liberalism should be postponed.

Like the local/global conundrum discussed above, this problem may seem worse than it actually is. The popular movements can tacitly cooperate with those domestic neo-liberals who are supporting demilitarization, state solvency and implementation of the peace accords, as well as with the IFIs. Recognition that neoliberals are better than death squads is not so hard to explain to the grass roots.

This does not mean that popular movements should keep quiet. 
I do not agree with O'Donnell and Schmitter's (1988) conclusion that popular forces should refrain from pressing socio-economic or political demands until the transition to polyarchy is consolidated. Robinson (personal communication) argues, and I agree, that strong popular movements in Guatemala can provide the support that the global and local neo-liberals need to push through peace accord implementation.

Once electoral democracy with popular participation is firmly in place the campaign against neo-liberal policies can commence in earnest. In the mean time the popular movements need to learn about the history of the world-system and the globalization project. This, and the pursuit of further international popular alliances, will make it possible for Guatemalans to benefit from, and contribute to, globalization from below. Global democracy begins at home.

\section{POSTCOMMUNISM}

The demise of the Soviet Union and the adoption of pro-marketization policies by the Chinese Communist Party led to the declared triumph of Reaganism-Thacherism as global neo-liberalism. The market is the regulator of both first and last resort. Policies of deregulation and privatization were accepted in nearly every corner of the Earth, and socialism/communism was declared a dead body. At the ideological level this was a massive shift. In most core states the gains of the labor movement and the institutions of the welfare state were rolled back or severely compromised.

The policies of deregulation, privatization and marketization were introduced in different ways in the postcommunist states. In the Soviet Union Gorbachev's moves toward glasnost and perestroika sparked national separatism among the non-Russian peoples of the Soviet Union. A failed coup to replace Gorbachev in 1991 instead led to the fall of one-party rule. It was replaced by a reformist regime that has made some efforts to introduce markets, privatization and deregulation. To some extent the former Communist managerial elite has transformed itself into a new capitalist class, but this class is also populated by others who have been able to use their political connections to gain control over profitable sectors of the economy.

The former structure of redistribution has mostly not been disassembled, but it is bankrupt. And little in the way of a functioning 
market economy has replaced it. The political process has succeeded in bringing off some fair popular elections, but these have not resulted in a legitimate government with an effective policy. At least for now the consequence is an economic disaster that may soon lead to a political disaster. The former Communist Party is sufficiently weakened that it cannot lead, but not so weak that it cannot stalemate the reformers. It may be that crisis and corruption will drive the populace to accept the order provided by charismatic nationalism. That kind of regime would not be likely to make much of a contribution to the construction of global democracy and indeed it might threaten world peace or implode.

In China, it was the Communist Party itself that introduced marketization policies. The old guard also learned from Gorbachev's mistakes. Rather than trying democracy first, they tried capitalism. To follow this road the gerontocracy found it necessary, in 1989 , to order a carefully picked contingent of the 'Peoples Liberation Army' to slaughter the students on Tienamen Squ-are. Having themselves been on the Long March, the elders had the grit to give these orders, and they eventually found soldiers who would do the dirty work, while the will to rule by force was largely gone from the Communist Party of the Soviet Union in 1991 when their moment came. It was Yeltsin on top of the tank who carried the day.

The Chinese path of reform has been, until now, much more successful in its achievement of rapid economic growth. Some of this has been due to the access that China has managed to negotiate for its goods in the American market. But, much of it has been due to the timing of the reforms in the policy cycle of building socialism that had been the trajectory of Maoist China. Mao had long understood that mobilizing millions of people depended on the cyclical shift back and forth between moral and material incentives. Slogans and cheerleading can get people going, but the effect wears off and the campaigners need to rest, and so material incentives return as a method for getting things done. This insight was built into the policy cycles by which socialist industrialization and agricultural development had been mobilized in China since the revolution. The shift to marketization and its 'moralization' by Party slogans such as 'Enrich Yourself' unleashed a huge flurry of economic activity at the roots of Chinese society. This was espe- 
cially true in the countryside where decommunalization released huge underutilized reserves of rural capital, labor and land. This was a potent combination of both moral and material incentives.

In Russia the Bolsheviks were long dead and the processes of informalization, the second economy, barter, reciprocity among kin and friendship networks, and the relegation of socialist ideology to ritualistic political and academic rhetoric did not provide such a fertile loam for the seeds of market freedom. In relation to dismal productivity, Soviet incomes were relatively high, even in the countryside. Crime, corruption and disorganization have prevented productivity gains, leaving real wages to fall where markets spread. After the Soviet demise the Russians expanded upon informalization of all kinds, but this did not produce a burst of economic growth as it did in China. The irony here is that, to a large extent it was the continuing organizational strength of the Chinese Communist Party that was able to mobilize marketized economic development in China, whereas a much weaker party in Russia could not do the same job.

The prodigious academic literature on postcommunism has attempted to comprehend the social and organizational changes that have occurred within the postcommunist societies in terms of a hypothesized transition from socialism to capitalism, and the implications of these changes for important theoretical issues in economic and institutional sociology (Nee and Stark 1989; Nee and Liedka 1997; Keister 1998). This literature has been quite fruitful for economic sociology, but with a few noteworthy exceptions there has been very little effort to place the phenomena of postcommunism into world historical perspective. The analysis of Chinese business groups within China and in the Chinese diaspora has given new life to the study of economic networks and social capital, as well as considerations of possible newly emergent forms of capitalism that could serve as the organizational model for the next epoch of global capitalism (Arrighi 1994). These topics have also been interwoven with considerations of the possibility of an emergent global hegemony of East Asia. The recent 'crisis' there, and new, or rather renewed, faultfinding about 'croney capitalism', might seem to have put the lid on all this. But the seers of East Asian rise (e.g. Frank 1998) make much of the fact that a global 
economic crisis began in Asia for the first time in centuries. The argument here is that, as in 1929, global crises begin at the center, not in the periphery.

The best work on postcommunism that utilizes world-systems concepts has been done on Central and Eastern Europe (Borocz 1992, 1993, 1999; Borocz and Smith 1995). While Borocz's analysis is broadly comparative, historically deep and develops important new world-systems concepts such as 'dual dependency', it is unfortunate that equally talented social scientific effort has not also been directed toward the ex-Soviet Union or China. Borocz's (1999) most recent study is careful in the ways that it pays attention to the important differences as well as the analytic similarities of the processes of social change in the Central and Eastern European countries. His pithy characterization of the postcommunist Eastern European regimes as 'auctioneer states' summarizes and compares the literature on emerging combinant property forms and class structures in these countries.

Borocz argues that most of the Eastern European countries are downwardly mobile in the larger core/periphery hierarchy because their former none-to-high situation of dual dependency (caught between Soviet imperialism and dependence on Western finance capital) is being replaced by an even greater degree of penetration by direct investment from global megacorporations. He also emphasizes that the breakup of many of the former states, which he argues was mainly motivated by hopes of early entry into the European Union, has increased the geopolitical volatility of the region and exacerbated the economic crisis. Borocz (1999) also cites comparative evidence on declines in life expectancy and the U.N.'s Human Development Index that support his contention that Russia and the Central and Eastern European postcommunist societies are moving down in the core/periphery hierarchy.

I agree that most of the postcommunist states in Central and Eastern Europe and the ex-Soviet Union are likely to experience downward mobility in the core/periphery hierarchy, but some of these states (perhaps the former East Germany, the Czech Republic, Hungary and Poland) may succeed in becoming incorporated into an expanded core region centered in the European Union in the next twenty years. Thus I predict a future bifurcation process in 
the development of the postcommunist states of Central and Eastern Europe with most experiencing peripheralization, but with a few managing to successfully move into the European core.

\section{GLOBALIZATION FROM BELOW IN THE POSTCOMMUNIST SOCIETIES}

The question I pose here is "what will be the role of the postcommunist societies in the struggle for global democracy?' In general I doubt that the postcommunist societies will be leaders in the future struggle for global democracy. Semiperipheral locations in the world-system have been, and will continue to be, fertile grounds for innovations and organizational implementations that can transform the logic of social development and lead to upward mobility in the core/periphery hierarchy. This phenomenon of transformational action emerging from the semiperiphery can be observed throughout the history of human social evolution, as argued and demonstrated by Chase-Dunn and Hall (1997). In the modern world-system those capitalist states that have expanded and deepened the commodification of the world-system (i.e. the Dutch Republic, the United Kingdom, and the United States) have all been former semiperipheral countries.

But not all-semiperipheral societies are transformative and upwardly mobile. It is our contention that the postcommunist societies are probably less likely to be innovators and leaders in future progressive transformations than other semiperipheral societies that do not carry the political baggage of having gone through a period of Communist government. I also predict that those postcommunist societies that did not have real revolutions of their own will be even less likely to take politically progressive paths. The legacy of having had Communist regimes imposed from without has created a strong antipathy to collectivist-rational organizational forms in these societies. This historical legacy even goes beyond the aversion toward state intervention that is a centerpiece of neoliberalism.

In addition, the processes of shock therapy in the implementation of market reforms have often led to political changes that are in the wrong direction from the point of view of democratic collective rationality. In Hungary, for example, the Hungarian Workers 
Party and its government had developed a system of productionbased regulation of environmental degradation, a system that has been advocated as a positive move toward sustainable development by industrial ecologists. This approach was dismantled and replaced by a much less effective end-of-pipe system of (de)regulation in the period of transition (Gille, forthcoming).

The efforts by Communist parties to bring about gender equality (e.g., professional jobs for women, child care facilities, etc.) were criticized by feminists for the aspects of patriarchy that remained, but the reactions against these institutions that have accompanied deregulation - e.g., the dismantling of day care for children - have accompanied and facilitated a massive reassertion of patriarchy in most of the postcommunist societies.

Several analysts of postcommunism have feared (or hoped) that the economic crisis of 'transition' might provoke populist or authoritarian movements that would react against the forces of capitalist globalization (e.g., Przeworski 1991). It has been supposed that the type of IMF (International Monetary Fund) riots that occurred in Latin America (Walton and Seddon 1994) might emerge in Eastern Europe. Greskovits (1997) notes that popular collective resistance to capitalist globalization has mainly not emerged in Eastern Europe and he seeks to explain the differences in this regard with Latin America.

Greskovits develops ideas from the social movement literature (Tilly 1978; Tarrow 1994) about the historically conditioned nature of popular collective responses to economic crises. The 'repertoire of contention' literature claims that the frames and organizational and tactical alternatives that are employed in resistance are specific to the regional and national histories in each case. Greskovits also utilizes Albert Hirschman's typology of 'exit, voice and loyalty' to understand the relatively low degree of contention in the Eastern European postcommunist societies in response to the crisis of 'transition'. It is Greskovits's claim that the historical consequence of patterns of resistance in Eastern Europe formed during the period of Soviet domination have led to the channeling of more recent resistance into individualist and informal 'exit' paths such as capital flight, hoarding, unsecured borrowing and remittance withholding rather than the exercise of public voice. 
While I agree that the institutionalization of informality and the second economy explains a large part of the economic differences between China and the ex-Soviet countries, I am skeptical of Greskovits's claim that this also explains why Eastern European populations have not mobilized against capitalist globalization. For one thing, the repertoire of contention in Eastern Europe during the Soviet age did include strikes and rebellions, especially in Poland, Hungary and Czechoslovakia. It is more likely to be the ideological and institutional aspects of historical legacies that better explain Latin American, Eastern European and Russian responses to the increased dependency and peripheralization that has resulted from capitalist globalization. Knowledge of organizational strategies and tactics fly around the world rather quickly during the modern age. These are not entirely or even largely matters of local habit. But what also flies around the world quickly is the ideology of the dead body of socialism, leaving globalized capitalism as the best world that is possible. This coordinated glorification and vilification resonates differently in distinct political and institutional contexts, and it is these differences that we propose will shape where the strongest anti-systemic movements will emerge within the semiperiphery and the periphery.

It is my contention that democratic socialist ideas for transnational alliances will be more successful in mobilizing people in those semiperipheral states that have not experienced Communist regimes. So the main contrast here is between all the postcommunist societies and the other semiperipheral countries. These differences are not ones of tactics, but rather of goals and conceptualizations of shared interests. Transnationally organized labor in coalition with women's, environmental and indigenous movements will eventually coalesce into a coordinated global movement led by a global party of democratic socialists ${ }^{4}$.

The idea of democratic and egalitarian collective rationality is not a new idea. It is basically the Left version of the European Enlightenment and it resonates with populist and egalitarian religious ideologies that are subtraditions of many civilizations and dominant traditions in most tribal and foraging societies 5 . These ideas are not new. And the word we use to label them does not really matter. But the very notion of egalitarian collective rationality is 
radically contested by neoliberalism. And that challenge resonates differentially with the political cultures that have been created by the historical sequences of different countries in the 20th century.

It is my main prediction that the next wave of anti-systemic movements will emerge most strongly in the semiperiphery. The most effective of these will be transnational movements that will act to create 'globalization from below' - the construction of collectively rational and democratic global institutions to manage and regulate the world economy, analogous to the nineteenth century movements to democratize national states. A major player in coordinating these movements will be a global political party - some kind of World Party or Network - that is dedicated to the building of a global democratic commonwealth. World citizens from all countries will participate in these movements and this party, but its main organizational support is likely to come from semiperipheral countries such as Brazil, Mexico, Korea and India. These countries do not carry the ideological and institutional baggage that the pioneers (and the victims) of state socialism bear. Their citizens and institutional structures are freer to innovate new forms of organization and ideology that can benefit from the lessons of the Communist states without being drowned by the heritages that those states bear.

This pattern of uneven development and 'advantages of backwardness' is rather typical of human social evolution. This is part of the reason why old core regions decline and semiperipheral regions emerge, so that the leading edge of evolution moves. The new twist here is that we are differentiating among semiperipheral players themselves rather than contrasting them with core or periphery.

It is also necessary to differentiate success in the global capitalist system from transformational action that contributes to building a more democratic and egalitarian world-system. While Russia and the Eastern European countries are experiencing downward mobility, China is arguably poised to become an important 'emerging market' that some claim might challenge the hegemony of Western capitalism. We are somewhat skeptical about China's possibilities in this regard, especially in the absence of a strong alliance between Japan and China. A Japan-China alliance is unlikely in the 
opinion of those who are familiar with the history of antagonisms and current public opinion in both of these countries. The careful study by Weede (1999) implies that China has a reasonable shot at moving up in the ranks of the semiperiphery, but we do not see China or East Asia as having a high potential for achieving hegemony in the global system.

As to China's potential for contributing to globalization from below, it suffers from most of the same problems that the other postcommunist societies do. As marketization and individualism grows, there will be considerable opposition to socialist ideas because of their association with an authoritarian state. In addition, the ideas of democratic collective rationality are suffering great dilution and confusion because of the current policy of promoting capitalism within an ideological framework that still sanctifies socialism. And the fascination with the slow but eventual establishment of representative Western style democracy and the real possibilities for successful capitalism will make China an unlikely context for the emergence of new anti-systemic movements. The same logic applies to those countries in Central and Eastern Europe who may manage to move into the European core in the next decades. The prospect of success within capitalism may undercut support for antisystemic movements.

I do not mean to say that no support for the new wave of global democracy will come from the postcommunist societies. Just as individuals and groups in the core and periphery will contribute, so will some from the postcommunist societies be able to transcend their local historical circumstances. Indeed, these will be needed to provide close testimony and knowledge of the positive and negative aspects of the Communist states and to constitute a representative basis for the World Party Network.

Within the category of postcommunist societies there are also important factors that will affect the strength of support for antisystemic movements. I have emphasized the important differences between those societies who had indigenous socialist revolutions vs. those that had Communist regimes imposed from abroad. I suppose the neither of these will be hotbeds of the World Party, but the victims of 'social imperialism' are even less likely to give a balanced consideration to the strategy of globalization from below. 
I have already mentioned the effects of upward mobility within global capitalism as negatively impacting antisystemic support. The converse would suggest that downward mobility would, other things equal, produce radical movements. But I can also imagine that a sort of J-curve might operate here, in which those who are near to upward mobility, or those that experience periods in which upward mobility seems to be occurring, might react to a downturn by producing a strong contingent of the global movement. It might also be supposed that recency of socialist revolution might be a differentiating factor, and so perhaps Cuba or Vietnam might be more likely than Russia to support new radical alternatives. More recent revolutions have generally not devolved to corruption to the same extent as older ones, and so disenchantment with collectivist ideas may not be so strong. But these finer points are admittedly controversial, as with all small differences.

In conclusion, the main point is that the semiperiphery remains the weak link of global capitalism - the structural region where the contradictions between core and periphery and between classes intersect powerfully to generate antisystemic movements. But I also add that the legacy of having already generated such movements in the past means that they are less likely to be generated in the same place in the future. I do not expect antisystemic movements to take state power through revolutionary upheavals again. Rather, the much larger proletariats of the non-postcommunist semiperipheral countries and the availability of support from allied groups in the core and the periphery will make it possible for these movements to win legal elections. This path will have a much better chance of avoiding the pitfalls of authoritarianism and war. That is why I am optimistic about the prospects for democratic socialism. But, as before, socialism in one country will not work. The semiperipheral socialist governments of the future will necessarily have to join the transnational movements for globalization from below.

\section{NOTES}

*An earlier version was presented at the panel on 'Prospects for Democracy and Justice in the Global Economy' at the annual meetings of the American Sociological Association, Washington, DC, August 16, 2000. 
${ }^{1}$ Shannon (1996) provides a helpful overview of the world-systems perspective as applied to the modern system.

${ }^{2}$ While integration and interdependence overlap, they are not exactly the same. Two entities may be linked by some kind of frequent interaction, but they may not be interdependent if the frequent interactions are not important. The exchange of food or other strategic raw materials is always more important than the exchange of luxury goods. Thus it is desirable to consider both the amount of exchange and what is exchanged.

${ }^{3}$ Unfortunately, this instance of proletarian internationalism was undone by Phillips-Van Heusen's recent exit from Guatemala.

${ }^{4}$ By socialism I simply mean democratic, egalitarian and collective rationality with regard to human interactions and relations with the biosphere. The word 'socialism' is not necessary, and is itself an oxymoron when applied to the world as a whole. I do not claim that this term is the cause of the differences that we predict will affect where support will come for globalization from below. But perhaps 'global democracy' would be a better short form for democratic collective rationality.

${ }^{5}$ Bollen and Paxton (1997) show that, in terms of egalitarian participation in collective decision-making, hunter-gatherer societies were much more democratic than the Athenian state that is alleged to be the institutional ancestor of modern Western democracies. The significance of this is that all human societies are ancestors of hunter-gatherers.

\section{REFERENCES}

Armbruster, R.

1998. Cross-Border Labor Organizing in the Garment and Automobile Industries: The Phillips Van-Heusen and Ford Cuautitlan Cases. Journal of World-Systems Research 4: 20-41 (http://csf.colorado.edu/wsystems/ jwsr.html).

Arrighi, G.

1994. The Long Twentieth Century. London: Verso.

Arrighi, G., and Beverly, S.

1999. Chaos and Governance in the Modern World-System: Comparing Hegemonic Transitions. Minneapolis: University of Minnesota Press.

Bairoch, P.

1996. Globalization Myths and Realities: One Century of External Trade and Foreign Investment. In Boyer, R., and Drache, D. (eds.), States Against Markets: The Limits of Globalization. London and New York: Routledge.

Bollen, K. A., and Paxton, P. M.

1997. Democracy before Athens. In Midlarsky, M. (ed.), Inequality, 
Democracy and Economic Development (pp. 13-44). Cambridge: Cambridge University Press.

Borocz, J.

1992. Dual Dependency and Property Vacuum: Social Change on the State Socialist Semiperiphery. Theory and Society, 21: 77-104.

Bornschier, V., and Chase-Dunn, C. (eds.)

1999. The Future of Global Conflict. London: Sage.

Boswell, T., and Chase-Dunn, C.

2000. The Spiral of Capitalism and Socialism: Toward Global Democracy. Boulder, CO: Lynne Rienner.

Boswell, T., and Peters, R.

1990. State Socialism and the Industrial Divide in the WorldEconomy: A comparative essay on the rebellions in Poland and China. Critical Sociology 17: 3-35.

Brenner, A.

1999. International Rank-and-File Solidarity: Labor's Democratic Response to Globalization. Paper presented at the annual meeting of the International Studies Association, Washington DC, February 20, 1999.

Chase-Dunn, C. (ed.)

1982. Socialist States in the World-System. Beverly Hills: Sage Publications.

Chase-Dunn, C.

1998. Global Formation: Structures of the World-Economy, $2^{\text {nd }}$ ed. Lanham, MD: Rowman and Littlefield.

1999. Globalization from below in Guatemala. Journal of Interamerican Studies and World Affairs. Special Issue on Guatemalan Development and Democracy.

(http://csf.colorado.edu/wsystems/archive/papers/c-d\&hall/toc.htm).

Chase-Dunn, C., and Podobnik, B.

1999. The Next World War: World-System Cycles and Trends. In Bornschier, V., and Chase-Dunn, C. (eds.), The Future of Global Conflict. London: Sage.

Chase-Dunn, C., Kawano, Y., and Brewer, B.

2000. Trade Globalization since 1795: Waves of Integration in the World-System. American Sociological Review, February.

Chirot, D. (ed.)

1991. The Crisis of Leninism and the Decline of the Left: the Revolutions of 1989. Seattle, WA: University of Washington Press.

Eckstein, S.

1994. Back from the Future: Cuba under Castro. Princeton, NJ: Princeton University Press. 
Engels, F.

1935. Socialism: Utopian and Scientific. New York.

Evans, P.

1995. Embedded Autonomy: States and Industrial Transformation. Princeton, NJ: Princeton University Press.

Frank, A. G.

1998. Reorient: Global Economy in the Asian Age. Berkeley, CA: University of California Press.

Frundt, H. J.

1987. Refreshing Pauses: Coca-Cola and Human Rights in Guatemala. New York: Praeger.

Gille, Z.

Forthcoming. 'State Socialism's Wasted Legacies: the Rise and Fall of Industrial Ecology in Hungary'. World Development.

Greskovits, B.

1997. Social Responses to Neoliberal Reforms in Eastern Europe. In Midlarsky, M. (ed.), Inequality, Democracy and Economic Development (pp. 269-289). Cambridge: Cambridge University Press.

Gordon, D.

1988. The Global Economy: New Edifice or Crumbling Foundation? New Left Review 168: 24-64.

1989. The Condition of Postmodernity. Cambridge, MA: Blackwell.

1995. Globalization in Question. Rethinking Marxism 8: 1-17.

Henige, D. P.

1970. Colonial Governors from the Fifteenth Century to the Present. Madison, WI: University of Wisconsin Press.

Jonas, S.

1991. The Battle for Guatemala: Rebels, Death Squads and U.S. Power. Boulder, CO: Westview.

Keck, M. E., and Sinkink, K.

1998. Activists Beyond Borders: Advocacy Networks in International Politics. Ithaca: Cornell University Press.

Keister, L. A.

1998. Engineering Growth: Business Group Structure and Firm Performance in China's Transition Economy. American Journal of Sociology 104, September: 404-440.

Lipietz, A.

1987. Mirages and Miracles: The Crises of Global Fordism. London: Verso.

Lipset, S. M.

1991. No Third Way: a Comparative Perspective on the Left. In Chi- 
rot, D. (ed.), The Crisis of Leninism and the Decline of the Left: the Revolutions of 1989 (pp. 183-232). Seattle, WA: University of Washington Press.

Lupher, M.

1996. Power Restructuring in China and Russia. Boulder, CO: Westview.

Markoff, J.

1996. Waves of Democracy: Social Movements and Political Change. Thousand Oaks, CA: Pine Forge Press.

McMichael, P.

1996. Development and Social Change: A Global Perspective. Thousand Oaks, CA: Pine Forge.

Mittelman, J. H. (ed.)

1996. Globalization: Critical Reflections. Boulder, CO: Lynne Rienner.

Murphy, C.

1994. International Organization and Industrial Change: Global Governance since 1850. New York - Oxford: Oxford University Press.

Hobsbawm, E.

1994. The Age of Extremes: A History of the World, 1914-1991. New York: Pantheon.

Nee, V., and Liedka, R. V.

1997. Markets and Inequality in the Transition from State Socialism. In Midlarsky, M. (ed.), Inequality, Democracy and Economic Development (pp. 202-226). Cambridge: Cambridge University Press.

Nee, V., and Stark, D.

1989. Remaking the Economic Institutions of Socialism: China and Eastern Europe. Stanford, CA: Stanford University Press.

Podobnik, B.

1999. Global Energy Shifts: States, Firms and Social Unrest in the Evolution of Commercial Energy Industries. Doctoral Dissertation, Johns Hopkins University.

Przeworski, A.

1991. Democracy and the Market: Political and Economic Reforms in Eastern Europe and Latin America. Cambridge: Cambridge University Press.

Robinson, W. I.

1996. Promoting Polyarchy: Globalization, US Intervention and Hegemony. Cambridge: Cambridge University Press.

1997. A Case Study of Globalization Processes in the Third World: a Transnational Agenda in Nicaragua. Global Society 2 (1): 61-91.

1998. Neo-Liberalism, the Global Elite and the Guatemalan Transi- 
tion: a Critical Macrostructural Analysis. In Chase-Dunn, C., Jonas, S., and Amaro, N. (eds.), Globalization on the Ground: Postbellum Democracy and Development in Guatemala. Lanham, MD: Rowman and Littlefield.

Ross, R., and Trachte, K.

1990. Global Capitalism: The New Leviathan. Albany, NY: State University of New York Press.

Rueschemeyer, D., Stephens, E. H., and Stephens, J. D.

1992. Capitalist Development and Democracy. Chicago: University of Chicago Press.

Shannon, R. T.

1996. An Introduction to the World-systems Perspective. Boulder, CO: Westview.

Silver, B.

1995. World Scale Patterns of Labor-Capital Conflict: Labor Unrest, Long Waves, and Cycles of Hegemony. Review 18: 155-192.

Silver, B., and Slater, E.

1999. The Social Origins of World Hegemonies. In Arrighi and Silver.

Soros, G.

1998. The Crisis of Global Capitalism. New York: Pantheon.

Stark, D.

1996. Recombinant Property in Eastern European Capitalism. American Journal of Sociology 101: 993-1027.

Stevis, D.

1998. International Labor Organizations, 1864-1997: the Weight of History and the Challenges of the Present. Journal of World-Systems Research 4: 52-75 (http://csf.colorado.edu/wsystems/jwsr.html).

Tarrow, S.

1994. Power in Movement: Social Movements, Collective Action and Politics. Cambridge: Cambridge University Press.

Taylor, P.

1996. The Way the Modern World Works: World Hegemony to World Impasse. New York: Wiley.

Tilly, C.

1978. From Mobilization to Revolution. Reading, MA: AddisonWesley.

1995. Globalization Threatens Labor's Rights. International Labor and Working-Class History 47: 1-23.

Wagar, W. W. Press.

1992. A Short History of the Future. Chicago: University of Chicago 
1996. Toward a Praxis of World Integration. Journal of WorldSystems Research 2: 1 (http://csf.colorado.edu/wsystems/jwsr.html).

Wallerstein, I.

1995. After Liberalism. New York: New Press.

1999. Utopistics. New York: New Press.

Walton, J., and Seddon, D.

1994. Free Markets and Food Riots: The Politics of Global Adjustment. Oxford: Blackwell.

Weede, E.

1999. Future Hegemonic Rivalry between China and the West? In Bornschier, V., and Chase-Dunn, C. (eds.), The Future of Global Conflict. London: Sage.

Wilmer, F.

1993. The Indigenous Voice in World Politics. Newbury Park, CA: Sage. 